\title{
Plays-within-Plays in Three Modern Plays: Michael Frayn's Noises Off, Tom Stoppard's The Real Thing and Alan Ayckbourn's A Chorus of Disapproval
}

Pilar Zozaya

Universidad de Barcelona

One of the techniques that authors have frequently favoured in the history of drama is the use of a play-within-a-play. Kyd's The Spanish Tragedy, Shakespeare's Hamlet, Buckingham's The Rehearsal, Sheridan's 'The Critic, Pinero's Trelawny of the 'Wells', and more recently Tom Stoppard's Rosencrantz and Guildenstern are Dead, The Real Inspector Hound and The Real Thing, Howard Brenton's The Churchill Play, Michael Frayn's Noises Off, Ronald Harwood's The Dresser, David Hare's A Map of the World, and Alan Ayckbourn's A Chorus of Disapproval -just to mention the most famous ones- have relied for part of their theatrical effect on the creation of an imaginary world inside a ficticious one, so they can juggle with the concepts reality and illusion, and interweave the different layers of fiction and metafiction.

One might wonder about the reason why this 'old' feature is still favoured by the most popular and successful of our contemporary playwrights. 'The answer may be rooted in the inherent qualities of this device. When an author inserts a play within another one, he is at once changing the general approach to his work of art. Some of his characters become 'actors' in the play embedded in the central piece, while others now take the role of the audience, thus becoming one with us. A close relationship is established between stage and public, and the footlights seem to disappear while we watch the new play 'together.' Notwithstanding the importance of this communion, this is not the sole motive that prompts the author to use this technique. A play within-a-play helps the playwright to reinforce, broaden and deepen the central motif in his main play; it becomes a very valid means to make his audience think about the fictionality of real life and the reality of fiction; and, if its form is that of the mock-rehearsal the playwright is furnished with the formula that will enable him to point out the flaws and enhance the virtues of the theatre, and to comment largely on the state of the theatre of his time.

To illustrate the enormous possibilities of this practice, we have chosen three plays by three contemporary playwrights: Michael Frayn's Noises Off (1982), 
Tom Stoppard's The Real Thing (1982), and Alan Ayckbourn's A Chorus of Disapproval (1984). These three plays have been selected, not only because they happen to be three great successes of modern English drama, but because they use the play-within-a-play formula with different purposes. As will be seen, in the case of Noises Off this technique helps the author to pay his devoted homage to the world of the theatre, in that of The Real Thing to express an intelligent comment on its fietionality/reality, and in that of A Chorus of Disapproval to mirror, deepen and reinforce the central theme in the main play.

\section{Noises Off}

In Michael Frayn's Noises Off, this technique of inserting a play within another one reaches its utmost possibilities, as the author plays each situation to the hilt.

This play was first performed at the Lyric Theatre, Hammersmith, on 23 February 1982, and transferred on 31 March to the Savoy Theatre, London. It was given The Best Comedy of the Year $\Lambda$ ward in 1982, and, after six years of unrelenting popularity, it is still playing to full houses. A similar success was achieved on Broadway - where it was also chosen as The Best Comedy of the Year in 1984-, and in Madrid in 1985. In the following year, the play was staged in Barcelona with yet another histrionic component that added an extra dimension to the fictitious element of fiction; the actors used two different languages: Catalan in Noises Off, Spanish in Nothing On.

Noises Off is a skilful, hilarious, farcical and, at the same time, loving comment on the very essence of the theatre, on the wizardry, and also on the drudgery, effort and pain needed to make a man's dreamt world come to life. Right from the moment we buy the programme, we are trapped by the rings of circles within circles of the plot, unable to draw a clear line between fiction and reality, as, next to the customary list of the cast, in order of appearance, name of director, etc..., we are pleasantly surprised when we realize there is a second Russian doll inside the first one: the cast of Nothing On. We are informed that the play was written by Robin Housemonger, directed by Lloyd Iallas, and that this is the 'World première prior to national tour.' This valuable information is followed by a long and detailed list of dates and times of performance, rules of the house, the production credits and the names of the sponsors -sardines, contact lenses, straitjacket and coffins are duly thanked to the different companies, and special mention is given to the European Breweries for their "generous support"Moreover, we are also given a summary of the successful careers of the actors, containing such interesting details as:

Garry Lejeune (Roger Tramplemain)... Recently made his 'big screen' debut in Up the Virgin Soldiers, for which be was nominated as Best Male Newcomer under Forty in any British L LowBudget Comedy Film by readers of the Sun newspaper.

Brooke Ashton (Vicki) is probably best known as the girl wearing nothing but 'good, honest, natural froth' in the Ilauptbahnhofbrau lager commercial. . Cinemagoers saw her in 'The Girl in Room 14, where she played the Girl in Room 312. 
Frederick Fellowes (Philip Brent)... was recently seen in the controversial all-male version of The Trojan Women.

l'oppy Norton-Taylor (Assistant Stage Manager) is from a family found more often on the Boards of leading companies than on the boards with wouring companies. .

'These witty digs at prize giving, advertising jargon, gratuituous changes in well established theatrical conventions, snobbery, etc., are the suitable introduction to a first Act where all the archetypal elements used in farces are mixed in a most ingenious combination. A new play -Nothing On- is going to open in 24 hours and the director-Lloyd Dallas-is having a dress rehearsal -not a technical one as some of his actors think. Working against time, and some other minutiae -like actors who do not know their exits and entrances, doors that do not open properly, and assistants who explode in sudden outbursts of anger and jelousy- the small company and its director manage, after many interruptions, to have a runthrough of a most interesting play that starts with a chatty help, Mrs Clackett who has not gone home yet because "they've got colour here, and it's the royal what's it called"[1], and a young man, Roger Tramplemain, who works for Squire, Squire, Ilackman and Dudley -the house-agents in charge of renting the "delightful sixteenth century posset mill. . . lovingly converted"-, and arrives accompanied by Vicki -"a desirable property in her early twenties"- with the idea of having a few hours of relax in the presumably empty house, he is passing off as his own. Ilowever their plan is thwarted by the arrival of Philip and Flavia Brent, who have come back home from Majorca for a few weeks, after having dodged the British Inland Revenue. With five people -a daily help and two couples- who should not be there, the play becomes an exciting game of hide-andseek, as they all keep on near-missing each other in their frantic exits and entrances. Things get really out of proportion when two other visitors arrive; the first one an old burglar, the second a real Arab Sheik who wants to rent a house.

In Nothing On Frayn has effectively included all the archetypal characters of a farce: a simplistic char with a soft spot for the aristocracy, and a certain malapropistic tendency; a young daring executive always ready for the sexual game; a dumb blonde, noticeable by her good looks and small brain; a modern, succesful writer, obsessed with escaping his duty as a tax-payer; a jealous wife easily provoked; and a scruffy old burglar who complains because of the facilities they give him to rob. However this is only one of the layers of our play as a second one-Noises Off- encircles and modifies it.

In the 'main' play, we are confronted with the 'real' characters behind those present in the rehearsed one. Here, again, we find plenty of farce in store with a whole gallery of comic types: the self-conceited actor who knows all the answers but can never articulate them in a coherent and complete sentence; the young actress hopelessly in love with the leading actor; the empty-headed starlet whose mistakes stop the rehearsal again and again; the insecure actor who needs to be given endless Stanislavskyan reasons to go on with the farce; the motherly actress always ready to cheer up the others and soothe the friction; the drunken actor constantly threatening the smooth running-on of the play; and, finally, 
among those in control of the show: a loud, sarcastic but also patient director, who is having a love affair with both the young starlet and his assistant, and who, when trying to control the chaos on stage complains: "I'm starting to know what God felt when he set put there in the darkness creating the world" (p. 376). However, they do manage to end the rehearsal, and Lloyd can finally shout: "Curtain!"

After the interval, the audience is immediately taken in by Frayn's audacity: 'The whole set has been turned through 180 degrees' and now, one month later, we are back stage while the actors and actresses are getting ready for an afternoon performance 2 | Affairs have been developing between the members of the company, and one of the sources of great comedy is to witness how the most innocent deed glimpsed by somebody who suddenly pops in has a totally different meaning and is the cause of endless rows and misunderstandings. Fray is still alluding to all possible levels of fietion and 'reality, 'truth and deceit.

This second act is specially effective when both the action on the stage and in the wings becomes one. This happens, for example, when in Nothing On, Roger, the young businessman, realizes there is something strange going on in that house as things keep on appearing and disappearing, and peculiar noises $|3|$ are heard all over the place; in Noises Off his shoe-laces have just been tied together by jealous Dotty, thus, when he makes his entrance, he falls over and enters Nothing On muttering his next line: "There's something evil in this house" (p. 454), which, obviously, has different and deeper undertones now. Similar effects are achieved in Act III. By now the audience knows quite well which are the lines, and the correct exits and entrances, therefore we enjoy the mistakes, changes and improvisations the actors are forced to make. This feature is also used to its utmost potential by having the silly dumb blonde delivering her lines just as the first time, unable to deviate at all from the script, impervious to all the changes the others are introducing. The whole play has to go on in spite of the problems; even if objects "move themselves on their own two feet," telephones are wrenched from the wall, sardines seem to be all over the place, and sheiks and burglars multiply without effort -by the end there are two prospective buyers and three thieves, all arriving on cue, and delivering their lines without fault, regardless of the fact that they keep on repeating everything. Actors and actresses fight wildly notwithstanding their tiredness, drunkenness, rage and jealousy; forgotten lines are invented, props are discarded, cues are missed, and the whole play becomes a frenzied race towards its end, as if the whole company believed that as long as the piece does not stop, nobody will notice anything, and the show will never be saved[4]. Nothing On ends with a joke on the sardines Mrs Clakett has kept cooking all through the play, Noises Off could go on forever.

Michael Frayn makes us laugh at modern plays, at directors, stage managers, actors and actresses, but we are also moved by the devotion with which all of them put their skills together in order to create such a fascinating world of fiction. The whole performance becomes an exciting theatrical event, with its misunderstandings, visual and aural jokes $|5|$, and ingenuous use of props the countless plates of sardines, the three bunches of flowers that are never given to the right person, the threatening fireman's axe, and the drunken actor's 
innumerable bottles of whisky-. Furthermore, the perfect synchronization of both plays, the ever increasing speed of the farce, and the frantic desperate finale make it an excellent piece to watch.

It might be argued that it is nothing but a simple farce, but we coujd report that this was just what Michael Frayn wanted to write. A farce that would be the epitome of all farces, a summary of all its clichés, types and situations, a homage to the genre and to the world of the theatre. Besides, he also attempts "to show something about the world" which, in this particular case, the author himself has summarised in the following terms:

\footnotetext{
The actors in Noises Off have fixed the world by learning roles and rehearsing their responses. The fear that haunts them is that the unlearned and unrehearsed - the great dark chaos behind the set, inside the heart and brain- will seep back on the stage. The prepared words will vanish. The planned responses will be inappropiate. Their performance will break down, and they will be left in front of us naked and unashamed 6 .
}

And, as we have just witnessed, the great dark chaos finally engulfs the stage.

Unlike Mr Frayn, who, so far, has used the world of the theatre in his plays just this once, our next playwright has made of this technique one of his most successful and idiosyncratic hallmarks.

\section{The Real Thing}

From the very beginning one of Stoppard's constant obsessions has been "the theatricality of theatre" as he believes that "theatre is not literature. It's an event"|7|. Therefore it is not surprising that very often he has pinpointed the very nature of theatre by breaking the barriers between fiction and 'real' life, and let one merge with the other before the dazzled eyes of a bewitched audience. We can get involved in the plight of two Elizabethan courtiers who only acquire their own personality when whirled into Shakespeare's Hamlet, as happened in Rosencrantz and Guildenstern are Iead (1966), or the dealings of two critics, who are trapped by the proceedings of the play they are about to review, as was the case in The Real Inspector Hound (1968), or the physical exercises of a group of jugglers who represent visually the acrobatic philosophic theories the main character is concerned with in Jumpers (1972), or the basic pattern of Wilde's 'The Importance of Being Ernest that shapes a study on art, literature and polities in Travesties (1974), but probably one of the plays where this opposition is more artfully exploited is in a piece whose core is precisely to find The Real Thing.

'The Real 'Thing, that opened at Strand Theatre on 16 November 1982, begins in Noël Coward fashion with Max discovering that Charlotte, his wife, who is supposed to have been on a business trip to Switzerland, has been unfaithful to him; his cool, ironic reaction makes her leave him. In the second scene, we see Charlotte living with another man, Ilenry, and we immediately presume he is the lover they mentioned in the previous one. Ilowever, we soon discover 
Stoppard has cheated us, as this is the 'real' life and the first scene was only part of the piece llenry wrote for his actress-wife to play in. With great ingenuity the author has destroyed our well rooted confidence, that makes us rely on our capacity to discern between what is real and what is not.

By choosing a playwright, two actors, two actresses and a rebel-martyrplaywright as the main characters in his new play, Stoppard can juggle with the notion of plays-within-plays to its utmost possibilities. In The Real Thing such technique acquires new power, as the author inter-links as many as four different plays, by four different dramatists, to give life to his own. Each one of them adds a new layer to the central core, and increases its meaning and depth by mirroring and commenting on the issues it presents - we might say that anything of importance takes place at least twice in the play, and sometimes even as many as three. 'Thus, for example, the scene in Ienry's piece-House of Cards-, with which the play begins, acquires only its full significance if we compare it to scene iii in the 'real' play - when Annie walks on Max-, and to scene ix -when Ilenry discovers Annie's adultery.

In House of Cards, Max can learn about his wife's infidelity and still be amazingly witty to continue to expound about digital watches, or joke about the number of lovers his wife has -he gradually moves from one, to "It's only two, is it?," then, "How do they all three get away at the same time? Do they work logether, like the Marx Brothers?," and, finally, "A string quartet, you mean?"[8]. However, when he has to face the same ordeal in real life-scene iii-, he can only react by abusing his wife with foul language, and assaulting her physically. In the second Act-scene ix-, it is Henry's turn to deal with a similar scene, and, once again, we realize real life is quite different from fiction. His ransacking Annie's belongings, his doggedly questioning her, and his attempt to blackmail her, differ totally from what he wrote in his play. Now, he does believe "in mess, tears, pain, self-abasement, loss of self-respect, nakedness" (p. 72).

By pointing to this disassociation between a real and a fictitious experience is Stoppard implying that the theatre fails to reproduce our actual feelings? Knowing the author, the answer undoubtedly is: no. In a much quoted interview|9| Stoppard described his writing as setting ambushes for the audience and, to my mind, this is what he is playing at here. Because, how do we know what the 'real' reaction is? By now Stoppard has shown us that we cannot rely on our discernment, in scene $i$ we made a mistake -it was fiction, not real life-, in scene vi, we greenly repeated the mistake, only the other way round -this time it was real life not fiction, the first few lines were only a joke between both actorsand in seene $x$ we fall into the same trap again: they are only rehearsing.

Furthermore, Stoppard has taken great care in structuring the three scenes (i.e. $i$, iii and $i x)$, establishing clear parallelisms between them, underscoring their similarities, and making them shine as three different facets of the same jewel. We conclude that theatre and life are nothing but 'the same thing.' Stoppard starts scene iii with a explicit stage direction in which he indicates that the two settings -those of scenes $\mathrm{iii}$ and $\mathrm{ix}$ - are "immediately reminiscent of the beginning of scene $i^{\prime \prime}$ (p. 35), then he recurs to use some of the most significant moments in Western drama[10] -as will presently be seen-, and ends by having llenry opening Annie's present, after her trip to Scotland, and finding a tartan 
scarf, which at once reminds us of the miniature Alp in a glass bow!, that Charlotte gave Max in House of Cards after her pretended visit to Switzerland. Stoppard also connects the first scene to other different moments in the play. For example, Max's searching of Charlotte's belongings, looking for her passport, is repeated by Annie -scene iv-going through Henry's papers, by Billy, Charlotte's new boyfriend, -sc. vii- in search of her diaphragm, and by Henry -scene ixtrying to find a proof against Annie.

'The other three dexterously inserted plays are also used to comment on the main one, and to highlight the principal theme. At a given moment in the piece scene iv-, Annie, who is going to play in Strinberg's Miss Julie, rehearses with Henry the famous love scene, but "she reads without inflection," and when he tries to approch her "she pushes him away." The scene not only comments on the artificiality of love, but it gives Ienry the opportunity to expound on his inability "to write love." "It is either childish or it's rude," he says "but it never sounds as the real thing" (p. 40). At this point Stoppard moves from fiction to reality in a very subtle way; Henry, triggered by the words in the rehearsed play, begins to ponder about how to express love in fiction, from these theoretical considerations, he moves to confess his 'real' love for Annie, but his tender avowal is cut in by the bud as the alarm clock in his wristwatch goes off. As Hearsh Zeifman observes[11], we immediately recall a famous similar sound which also stopped another 'theatrical' situation: the alarm clock at the beginning of 'The Maids.

Later on in scene $v$, Henry reads from the play written by Brodie -a Marxist soldier jailed after trying to set fire to the Cenotaph by kindling the wreath deposited there-, and uses this third place as his spring-board to start a witty and brilliant speech about real literature and trash|12| -ironically enough he has to admit that as long as his wife does not marry again he will not be able to write "the real stuff." In scene vi, Billy and Annie repeat the first lines of this play as a gambit in his amorous approach to her; in scene $x$, they rehearse the play for the television, surprisingly enough every time Stoppard succeeds in taking us by surprise, and making us reconsider our conception about reality and fiction. This very same effect is achieved by the fourth play enmeshed in The Real Thing; I am referring to "Tis a Pity She's a Whore by Ford. Annie plays in it together with Bill and, both at the end of scene vi, and in scene viii, we notice that the boundaries between reality and artificiality have been dramatically blurred once more; the lovers in the play are now becoming lovers in real life, and Annie, like Annabella, is a whore, an adulteress.

'The play has then as its core the opposition 'real life' and 'fiction' but, as has become evident by now, the author means 'the real thing' in all aspects of life. He tries to distinguish between real love and colonisation, real music and sham, real literature and trash, real politics and propaganda, real sex and biology, real self and our masks, and being really committed or only using a given system; characteristically he does not give the precise and unique answer. 'The play has coiled and wound so often between its own statements and counter-statements, has zigzagged with such skilfulness between 'the real' and 'the faked' that we are left still looking for 'the real thing.

When watching the play we are immediately bewitched by Stoppard's dazzling verbal games, his witty puns and clever jokes -we are on familiar ground-, 
however the play soon reverts to more serious matters, and, prompted by the desire to prove the opposition between reality and artificiality, baffles the audience with the shocking audacities it runs into when combining both worlds. In other instances he even bores them with the conversationality and shallowness of the lines, and, in spite of all the ingenious gimmicks used, we remain 'painfully' unmoved, unaffected by the author's cleverness and skill. We might say, paraphrasing his famous scene about the wooden clubs and cricket balls, that the ball has only travelled a few feet and we are left with sore hands.

Therefore, 'The Real 'Thing is probably one of the very few pieces in which the use of a play-within-a play does, in the end, work against its general effect. The continuous shifting of the action between two different levels of fiction contributes to a progressive distancing and to a notorious estrangement between actors and audience. Fortunately this is not the case with our next play.

\section{A Chorus of Disapproval}

Like all Alan Ayckbourn's previous works, A Chorus of Disapproval was first staged at the Stephen Joseph Theatre-in-the-Round, Scarborough -the première took place on May 22, 1984-, and was subsequently transferred to London. However with this new play Ayckbourn has accomplished yet another real feat, as was not only been produced at the National Theatre - which had already been the case with Bedroom Farce in 1977-, but it has been his first play to have reached the main auditorium: the Olivier stage. IIis old dream has finally come true| $13 \mid$.

Taking as the basis of his play the dealings of a group of amateur operatic singers involved in the production of The Beggar's Opera, Ayckbourn has created another of his true and effective comedies about our modern society, about the hero 'malgre lui, who, without really wanting to, is raised to the very top, by those who want to use him, only to be thrown down from his pedestal once he proves not to be what they had taken him for. As Sheridan Morley remarks: "lle exists purely in the eyes of others," and this fact "allows the author to make his usual points about the unthinking cruelty of a supposedly neighbourly society vastly more coherently and powerfully than usual"[14].

The play begins with the always thrilling experience of a play-within-a-play. The open stage of the Olivier becomes alive with the enthusiastic rendering, by an amateur group called PALOS (i.e. The Pendon Amateur Light Operatic Society), of the final notes of 'The Beggar's Opera. 'The song ends and 'their' audience explodes in greal applause, obligingly Dafydd ap Llewellyn, the energic, enterprising, life and soul producer, springs from the auditorium on to the stage to thank all of them. After expressing his most sincere gratitude and thanking audience and singers alike, the sound of applause dies and all the artists leave without even congratulating their leader, who is left on his own on the vast, empty stage. He begins to take off his wig and hat, jacket and cravat; a woman hands him his ordinary clothes, as she mutters softly "well done"; then the singer finishes changing, while the lighting turns to harsh working lights. 
'This is the end of 'our' play, now Ayckbourn, in an extended flashback will disclose how Guy Jones came to sing, as Macheath, the leading figure in the opera, and why nobody acknowledges him in his triumph.

As usual Ayckbourn excels in his characterizations, in presenting his suburbanites and their petty tragedies. The play is centred upon shy, easy-going, obliging, diffident Guy Jones, the widower who wanting to start anew and looking for company decides to join an amateur operatic society. He is the typical Ayckbourn character 15 l, a nobody -as Dafydd accurately tells his wife early in the play-, who, due to his mute acceptance and passive attitude, disrupts the established system. He is not lascivious, greedy or scheming but, like all great heroes, he has a fatal flaw: he cannot say 'no.' Due to this unfortunate shortcoming, he accepts the sexual advancements of two married ladies, promises to enquire about the plans for expansion the multi-national company he works for has, and informs the owner of the piece of land in question, about the plot against him. Ilis sexual exploits, and definitive participation in the financial intrigue mirror his dizzy career in the operatic society, as he zooms from walk-on to the lead. But so much success does not unfortunately conclude with happiness. The fall of his company means the end of his rise, his good fortune forsakes him, and his kleptomania is condemned by a unanimous chorus of disapproval. As Martin Hoyle has summarised: "with the Ayckbourn irony, he ends up despised, vilified and mistrusted"[ 16].

Another felicitious creation is mad, garrulous, enthusiastic, big-mouthed Dafydd ap Llewellyn. He is the director who cries: "I wish to God they were professionals. Then I could sack them"[17]. The courageous artist who only loses heart when things really begin to get out of control -"Trying to do The Beggar's Opera without a Macheath is a bit of a non-starter even for Peter Brook" (p. 53). The husband who complains about his wife: "She's a bloody deep-freeze woman" (p. 53), unaware of the fact that this very woman is having a very 'hot' sexual relationship with the man he is confiding in.

As always in Ayckbourn, the play teems with moments of great humour; they spring from situations, misunderstandings, similes, repelitions, exaggerations...always advancing the plot and defining the characters. This is the case, for example, in the following exchange -here, we not only 'enjoy' the crude joke, but also gain more insight into Dafydd's personality-:

IIanna... Is your wife local?

Dafydd No, dearest, he hasn't got a wife...

llanna No?

Guy No she died... she died, recently.

LIanna Oh, dear.

Dafydd Oh dear, I didn't know that. Accident, was it?

Guy No. Not really it was... (He searches for words)

Dafydd Deliberate. (He laughs)

Hanna (Fiercely) Dafydd...

Dafydd Sorry, sorry. I do beg your pardon. I'm sorry, Guy (p. 22). 
All the other characters are also well contrasted and easy recognizable types, and, as could be expected in a play that is going to be counterpointed by The Beggar's Opera, women are particularly well characterised. Hannah Llewellyn is the typical Ayckbourn down-trodden wife, who, like Belinda in Season's Greetings craves for a little bit of attention and love. While Fay Hubbard plays the role of the local siren, who likes experimenting sexually with "anything at all. Well, I suppose if it was excessively cruel or painful. . I could draw the line" (p. 35), and shows what sex can do to a woman, whereas Rebecca Huntley-Pike, a ridiculous self-pitying character, proves what the lack of it can do to another one.

Technically the play is a most ingenious contrivance. As we have already mentioned, it begins with the last scene and then proceeds to develop an extended flash-back that expounds the reason why nobody congratulates Guy on his moment of triumph. 'To have chosen The Beggar's Opera, as the piece to counterpoint his own, is one of Ayckbourn's achievements. The songs from Gay's politial satire become a most excellent comment on a new piece; they reflect and mirror exactly the events happening in the main action, and therefore deepen and broaden its particular subject, making it universal. In A Chorus of Disapproval we not only find the sexual passions that ravaged the eighteenth century opera, but also the greed and corruption of its rascals. Ayckbourn's characters prove that even the quiet members of a jovial amateur operatic society may become ferocious sharks when it comes to land-deals. As Ronald Hayman has remarked: "It seems absurd to compare both playwrights but, like Brecht, Ayckbourn finds that the rapacity of Gay's highwaymen and the double standards of his respectable middle-class citizens have precise equivalents in modern society. Ayckbourn's satire, of course, is gentler and more local than Brecht's"[ 18].

As could be expected, the play was received with great applause and general favourable reviews. Thus, for example, Ronald Hayman wrote in Plays International: "One of his best plays yet. . . splendidly entertaining evening, with enough laughter in it to cure all the most cronic of depressions"| 19], and Sheridan Morley stated in Punch: "It is in my view far and away the most successful of his more recent and bleak journeys into mid-life crisis"|20|. While John Peter summarized the event in 'The Sunday Times with these laudatory words:

The London première of Alan Ayckbourn's A Chorus of Disapproval is a major event. When I saw it in Scarborough last year I thought it was sharp ingenious and slightly prunable. Now, with the National's 24-carat cast, it reveals itself as a serious comic masterpiece: brilliantly constructed, ruthlessly observant, hilarious, and hard as nails|21 ].

Notwithstanding these complimentary terms, Alan Ayckbourn has also had his share of recriminations. He has been accused of 'writing too much'|22|, and often his plays are dismissed on the grounds of being too trivial. To my mind, these reservations are often due to a general wilful refusal to recognize the depth, the darkness embedded in much of his work. His recurring themes are: "insensitivity, egoism, domineering arrogance, the joylessness of middle-class marriage, the hollowness of social and family rituals, parental 
misunderstanding, our repeated failure as human beings to find ways of living together or communicating with each other"[23], and as has been pointed out these subjects suggest Ibsen, Checkhov and Strinberg[24]. Like a new Jane Austen, he is interested in showing 'the follies and nonsense' of the middle classes, in pilloring their manners and social conventions. His observation of the minutiae of human relationships in general, and of the deadly struggle between husband and wife in particular, is accurate, sharp and to the point, and it should be noticed that, in every new play, it is becoming darker, and more and more lethally accurate. And although the tone is that of irrepressible laughter and farcical humour, the scathing satire, the wry irony, the seriousness and tragicomedy of everyday life is also present in all his works.

We might say that Alan Ayckbourn has succeeded in depicting the un-heroic tragicomedy of our monotonous life with great preciseness, and, as Peter Hall foresees: "In 100 years' time, when he's been forgiven for being successful, people will read his plays as an accurate reflection of English life in the 1960s, 70s and 80 s. They represent a very important document"[25].

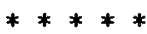

This has been our analysis of the use of an old technique by three modern playwrights. We conclude that, even if in the case of The Real Thing it did not prove to be altogether satisfactory, in the other two instances, the possibility of using the stage to reflect its own characteristics and to comment on its very essence enhanced the theatricality of the whole experience. The boundaries between fiction and reality are dramatically blurred, and, once more, we admit that 'the whole world is a stage.'

NOTAS

1. Michael Frayn, Noises Off (Plays: One) (London: Methuen, 1985), p. 366. All further page references will be cited in my text.

2. In this particular aspect (i.e. having the actors perform again the play), Michael Frayn, as Katherine Worth points out, has probably taken "a tip from Beckett's Play as well as from Pirandello." "Farce and Mr Frayn," Modern Drama, XXVI, 1 (March 1983), 47-59.

3. Noises is all Frayn lets his actors utter backstage. In perfect silent movies tradition, actors can only express their passions through gestures, looks, mime..., and the whole performance becomes a wonderfully exhilarating experience underseored by its perfect synchronization with the other play. 
4. The author himself has said about Noises Off that the play "attempts to spotlight the front that people put up all the time and the fact that they will do anything so long as they keep up appearances." Quoted by Peter Kemp in 'The Times Literary Supplement, 5.3.82.

5. As J. R. Taylor praises "when even the oldest one in the book, about the cactus someone is inevitably going to sit on, can be milked for so much genuine laughter, something must be going on spectacularly right." Plays and Players, (April 1982), p. 24.

6. See Introduction to the volume-Plays: One-published by Methuen, p. xii.

7. Quoted by Tim Brassell when interviewed by Melwyn Bragg in "The South Bank Show," LWT, broadcast on 26 November 1978. Cited in 'Tim Brassell, Tom Stoppard: An Assesment (London: MacMillan, 1985).

8. Tom Stoppard, The Real Thing (London, Faber \& Faber, 1986), p. 14. All further page references will be cited in my text.

9. "Ambushes for the Audience: T'uwards a Iligh Comedy of Ideas," (Tom Stoppard interviewed by Roger Hudson, Catherine Itzin and Simon Trussler), Theater Quarterly, IV, 14 (1974). Reprinted in New Theatre Voices of the Seventies, ed. Simon Trussler (London: Methuen, 1981), pp. 58-69.

10. In a most interesting study of the play, Hersh Zeifman has accurately pointed to the significant fact that the play starts with Charlotte -in House of Cards-slamming the front door and making Max's pyramid of cards collapse, thus reproducing visually the breaking up of their relationship, and alluding to another shattered marriage as well, and to another famous door-slam, that of Nora's at the end of Doll's House -we should also remember here that at a given moment Debbie, Henry's daughter, calls him "Henry Ibsen"-; another literary reference is Max's proof of Annie's infidelity: a hand kerchief. See Hersh Zeifman, "Comedy of Ambush: Tom Stoppard's The Real Thing," Modern Drama, XXVI, 2 (June 1983), 139-149.

\section{Hersh Zeifman, ibid, p. 145.}

12. The memorable image usied by Henry to explain to Annie the difference between good and bad writing is one of the best moments in the play: "This thing here . . is for hitting cricket balls with. If you get it right, the cricket ball will travel two hundred yards in four seconds... What we are trying to do is to write cricket bats, sis that when we throw up an idea and give it a little knock, it might...travel... Now what we've got here is a lump of wood ... and if you hit the ball with it, the ball will travel about ten feet and you will drop the bat and dance about shouting 'Ouch!' with your hands stuck into your armpits." (p.52). For an intelligent analysis of this scene see Thomas R. Whitaker, Tom Stoppard (London: MacMilian, 1983), p. 165.

13. As he told lan Watsun in 1980: "I'd love to conquer the Olivier. I think it 'is'possible to do a modern play there and I think it 'is' possible to do a modern comedy there." lan Watson, Conversation with Ayckbourn (London: MacDonald Futura Lid., 1981), p. 159.

14. Sheridan Morley, Punch, 14.8.85, p. 47. 
15. We had already met him/her, for example, in Way Upstream -Alistair-, Absurd Person Singular-Eva-, in Bedroom Farce-Nicky-.

16. Martin Hoyle, Plays and Players, No. 385 (October 1985), p. 30.

17. Alan Ayckbourn, A Chorus of Disapproval (London: Samuel French, 1985), p. 47. All further page references will be cited in my text.

18. Ronald Hayman, Plays, (September 1985), 1, 2, 26.

19. Ronald Hayman, ibid., p. 26.

20. Sheridan Morley, Punch, 14.8.85, p. 47.

21. John Peter, The Sunday 'Times, 4.8.1985.

22. As Peter tlall has already warned him: "if you didn't write so much, they'd realise you are quite good." Quoted by Ian Watson, op. cit., p. 172.

23. Michael Billington, Alan Ayckbourn (London: MacMillan,1983), p. 170.

24. In 1980, the author explained the new aim he had set himself: "I want to move further into the Chekhovian field, exploring attitudes to death, loneliness, etc. -themes not generally dealt with in comedy." lan Watson, op cit., p. 129.

25. Quoted by Michael Church, "Shakespeare of the South Bank," The Sunday Times, 1.6.1986, pp. 41-42. 